\title{
Sensory evaluation of black instant coffee beverage with some volatile compounds present in aromatic oil from roasted coffee
}

\author{
Análise sensorial de bebida preparada com café instantâneo com alguns \\ compostos voláteis presentes no óleo aromático de café torrado
}

\author{
Alessandra Lopes de OLIVEIRA ${ }^{1 *}$, Fernando Antonio CABRAL ${ }^{2}$, \\ Marcos Nogueira EBERLIN ${ }^{3}$, Helena Maria André Bolini CORDELLO ${ }^{4}$
}

\begin{abstract}
Resumo
O óleo do café torrado Brasileiro obtido através de extração com $\mathrm{CO}_{2}$ supercrítico mostrou consideráveis propriedades aromáticas, constituído principalmente por cinco compostos aromáticos: 2-metilpirazina; 2 -furfuril álcool, 2,5-dimetilpirazina; $\gamma$-butirolactona e 2 -furfuril acetato. Análises sensoriais foram usadas para verificar a influência da mistura destas importantes classes de compostos aromáticos de café (pirazinas, furanos e lactonas) e do óleo aromático de café torrado no aroma e sabor de bebidas preparadas com café solúvel instantâneo liofilizado e seco por spray dryer. $\mathrm{Na}$ análise da aceitação do aroma, a amostra preparada com café liofilizado sem a mistura de compostos voláteis (amostra 4) não diferiu da amostra de café liofilizados com adição de óleo (amostra 5) nem tão pouco da amostra de café liofilizado com adição da mistura dos cinco voláteis (amostra 3), coincidentemente oriundas do mesmo processo de secagem. Entretanto a amostra 3 não diferiu das amostras preparadas com café seco por spray dryer sem (amostra 1) e com (amostra 2) a mistura de voláteis. Indicando que a adição desta mistura, com relação a este atributo não interfere na aceitação desta bebida. Na avaliação do sabor, as amostras preparadas com café solúvel liofilizado enriquecida com óleo aromático (5) e as amostras com (3) e sem (4) a mistura dos cinco voláteis não diferiram significativamente, entretanto a amostra (4) não diferiu das amostras (1) e (2). Para este atributo, a adição do óleo aromático de café torrado ou da mistura de voláteis nas amostras de café liofilizado fez com que tivessem uma melhor aceitação que aquelas secas por spray dryer (1) e (2). Desta forma, o enriquecimento das bebidas com o óleo aromático de café torrado, ou mesmo com a mistura dos cinco componentes não influenciou a aceitação do consumidor com relação ao aroma, mas exerce influência com relação ao sabor.
\end{abstract}

Palavras-chave: café; oleo de café; aroma; pirazina; lactona.

\begin{abstract}
The oil obtained from Brazilian roasted coffee by supercritical $\mathrm{CO}_{2}$ extraction shows considerable aromatic properties, mainly composed by five aromatic compounds, 2-methylpyrazine; 2 -furfurylalcohol, 2,5-dimethylpyrazine; $\gamma$-butyrolactone and 2 -furfurylacetate. Sensory analyses were used to verify the influence of a mixture of these important classes of aromatic coffee compounds (pyrazines, furans and lactones) and of the roasted coffee aromatic oil on the coffee aroma and flavour of black instant freeze and spray-dried coffee beverages. In the acceptance evaluation of the aroma, the samples prepared with freeze-dried instant coffee without the mixture of volatile compounds (sample 4) were not significantly different from the freeze-dried instant coffee in which the aromatic coffee oil was added (sample 5) and from the sample prepared with freeze-dried coffee in which the mixture of the five volatile was added (sample 3), coincidentally from the same drying process. Therefore, sample (3) did not differ from samples prepared with spray dried instant coffee without (sample 1) and to which (sample 2) the mixture of volatile was added. Therefore, with respect to this attribute, the addition of this mixture did not interfere in this drink acceptance. Taking into consideration the flavor, samples prepared with freeze-dried instant coffee in which the aromatic coffee oil was added (5) and the samples with (3) and without (4) the mixture of the five volatile was added did not differ significantly, however sample (4) did not differ from samples (1) and (2). Regarding this attribute, the addition of the aromatic oil of roasted coffee or a mixture of volatile in samples of freeze-dried instant coffee had a better acceptance than those dried by spray dryer (1) and (2). Thus, the enrichment of drinks with the aromatic oil of roasted coffee, or even with the mixture of the five components did not influence the consumer acceptance with respect to the aroma, but exerts influence with respect to flavour.
\end{abstract}

Keywords: coffee; coffee oil; aroma; pirazyne; lactone.

\footnotetext{
Recebido para publicação em 2/7/2007

Aceito para publicação em 28/10/2008 (002645)

Department of Food Engineering - ZEA, Faculty of Animal Science and Food Engineering - FZEA, University of São Paulo - USP, Av. Duque de Caxias Norte, 225, CP 23,

CEP 13635-900, Pirassununga-SP, Brazil,E-mail: alelopes@usp.br

${ }^{2}$ Department of Food Engineering - DEA, Faculty of Food Engineering - FEA, State University of Campinas - UNICAMP, CEP 13083-970, Campinas - SP, Brazil

${ }^{3}$ Institute of Chemistry - IQ, State University of Campinas - UNICAMP, CP 6154, Barão Geraldo, CEP 13083-970, Campinas - SP, Brazil

${ }^{4}$ Department of Nutrition - DEPAN, Faculty of Food Engineering - FEA, State University of Campinas - UNICAMP, CEP 13083-970, Campinas - SP, Brazil

${ }^{*}$ A quem a correspondência deve ser enviada
} 


\section{Introduction}

The study of the aroma and flavor of food generally involves the aromatic extract composition knowledge. Coffee extracts of the aromatic and lipid fractions are normally called "roasted coffee aromatic oil". Coffee extracts are considered high value products for beverage and alcoholic beverage, bakery, and even instant coffee industries. The quality of coffee extracts obtained using different extraction methods were recently compared by Sarrazin et al. (2002), who studied which method provided an extract with sensory characteristics as close as possible to that of coffee. Ramos et al. (1998) and Oliveira et al. (2001), also trying to obtain roasted coffee aromatic oil with an aroma as similar as possible to that of the original brewed coffee, optimised the operational variables of the supercritical $\mathrm{CO}_{2}$ extraction based on the sensory analysis of the aromatic extract.

The aromatic fraction of roasted coffee oil is complex involving more than 800 compounds with different functional groups (NIJSSEN et al., 1996). Various studies on coffee aroma have tried to identify which aromatic compounds could individually be considered as powerful constituents of coffee aroma (HOLSCHER; VITZTHUM; STEINHART, 1992; SEMMELROCH; GROSCH, 1995; POLLIEN; KREBSD; CHAINTREAU, 1997; MAYER; CZERNY; GROSCH, 2000). Among these studies, Semmelroch and Grosch (1996) tried to identify the most important coffee odorants (Coffea arabica and Coffea canephora var. Robusta) preparing and testing aroma solutions in sensory experiments. Those studies have contributed to research studying the influence of the key odorants present in coffee beverages (MAEZTU, 2001) or coffee beverages containing an increased amount of these compounds (BLANK; GROSCH, 2002; BASSOLI et al., 1993).

Elmore e Nursten (1993) studied the effect of 2-furanmethanethiol, which has an aroma of fresh coffee according to previous studies, and its ability to increase the flavour of instant coffee. For both black and white coffee, they found a significant preference for samples containing 2-furanmethanethiol with concentrations above 100 p.p.b. when compared to a reference sample. Blank e Grosch (2002) studied the influence of 2-methylisoborneol which has been reported as an off-flavour compound in drinking water and foods but as a key flavor in Robusta coffee. The sensory results showed that there was no similarity with the reference Robusta sample.

The coffee drying method has also proved to have a significant effect on the aroma and flavor characteristics of instant coffee. Freeze-drying and spray drying are the most frequently used methods to produce instant coffee. In the freeze-drying method, the concentrated coffee extract is initially frozen and then milled. Next, the frozen granules are sifted before drying to ensure uniform sizes. In this process, a few changes in aroma are caused by heating and oxidation since the moisture is sublimed in a vacuum chamber. Spray drying is another major processing technique. Concentrated coffee extract is atomised in a drying chamber from which the water is removed due to the contact with air at temperatures between 200 and $300^{\circ} \mathrm{C}$. This technique allows large-scale production and provides products with low density and good flowability. Due to the relative simplicity of the equipment, the production costs are low. The inconveniences of spray drying processes are the losses of aroma and the caramel flavor imparted to the product (BASSOLI et al., 1993).

Sensory evaluations of different commercial instant coffee have been carried out to assess the different quality of those products in the market (CALVIÑO; ZAMORA; SARCHI, 1996; ZAMORA; CALVINO, 1996; JONG; HEIDEMA; VAN DER KNAAP, 1998). The quality attribute is associated with the beans, storage time, fermentation process, roasting, extraction of the soluble solids, and the packaging material. Considering that the roasted coffee oil obtained by extraction with supercritical $\mathrm{CO}_{2}$ has considerable aromatic properties and that the sensory analysis is an important tool in the analysis of coffee aroma, the current work aimed to measure the influence of the addition of a mixture of five aromatic compounds to beverages prepared using samples of spray and freeze-dried instant coffee. These compounds were found in high concentrations in the roasted coffee aromatic oil, obtained by supercritical $\mathrm{CO}_{2}$ extraction (OLIVEIRA; CABRAL; EBERLIN, 2003). They were chosen to compose the aromatic mixture since they represent important classes of compounds of coffee aroma: pyrazines (2-methylpyrazine; 2,5-dimethylpyrazine), furans (2-furfurylalcohol; 2-furfurylacetate) and lactones ( $\gamma$-butyrolactone) (MAEZTU et al., 2001; WANG; SHANFIELD; ZLATKIS, 1983; HASHIM; CHAVERON, 1996; ROBERTS; POLLIEN; MILO, 2000). This mixture, represented by the three classes of compounds present in roasted coffee, has not yet been investigated. In this work, sensory analysis was used to verify if this mixture could enhance the characteristic coffee aroma and flavor of black instant coffee beverages and consequently increase consumer preference for beverages prepared with instant coffee.

\section{Materials and methods}

\subsection{Raw material}

Instant coffee was prepared as a blend of Arabica and Robusta coffee varieties dried using two different methods, spray drying and freeze-drying. They were processed by COCAM (Brazilian Company of Soluble Coffee and Derivatives) which donated the samples for the experiments. Before the samples left the factory, roasted coffee aromatic oil was added to one of the freeze-dried samples. This aromatic oil was obtained by pressing roasted Arabica coffee beans which were also obtained from COCAM ( press extraction method).

\subsection{Beverage preparation}

For the sensory analysis, five black instant coffee beverages were prepared adding $2 \mathrm{~g}$ of instant coffee to $150 \mathrm{~mL}$ of hot distilled water. The samples were prepared in the same way for both the triangle and acceptance tests (Table 1). The water was treated to avoid the influence of some different solutes it might contain although Rivetti et al. 2001 showed no significant differences between tap and treated water in percolated espresso coffee. Hot distilled water (approximately $70{ }^{\circ} \mathrm{C}$ ) was added to the soluble coffee together with the aromatic solution at the time of serving, and each taster tasted the beverage as usual. The coffee beverages were prepared fresh in a thermostatically controlled 
Table 1. Samples order of presentation.

\begin{tabular}{cc}
\hline Samples & spray-dried instant coffee without the \\
mixture of compounds \\
2 & $\begin{array}{r}\text { spray-dried instant coffee to which the } \\
\text { mixture of compounds was added } \\
\text { freeze-dried instant coffee to which the } \\
\text { mixture of compounds was added } \\
\text { freeze-dried instant coffee without the } \\
\text { mixture of compounds }\end{array}$ \\
4 & $\begin{array}{c}\text { freeze-dried instant coffee to which the } \\
\text { aromatic roasted coffee oil was added }\end{array}$ \\
\hline
\end{tabular}

flask $\left(70{ }^{\circ} \mathrm{C}\right)$, and the temperature was kept constant until the sensory evaluation, but the time between the samples preparation and sensory testing was very short, less than 15 minutes, to minimize aroma loss.

\subsection{Preparation of the volatile solution and preliminary examination of the detection threshold of the compounds mixture in the coffee beverage}

The volatile solution was prepared in ethyl alcohol at a concentration of $0.1 \%$ for each of the five high purity compounds (Aldrich Co., Milwaukee, WI, USA). Preliminary sensory evaluations were carried out to verify whether the presence of this solution (ethyl alcohol, 2-methylpyrazine; 2-furfurylalcohol; 2,5-dimethylpyrazine; $\gamma$-butyrolactone and 2 -furfurylacetate) could be detected in the black instant coffee beverage. Eight untrained tasters were requested to verify the impact of this mixture so that it would not interfere negatively in the characteristic coffee aroma and flavor of the beverages. Aroma was considered the impression obtained by orthonasal perception and flavor was the combined effect of the aroma and taste perceptions.

In order to determine the impact of this solution in the black instant coffee beverage, the triangle test was used, as described in the following section. The initial concentration of these compounds in the beverage was 100 p.p.b., and it was verified that this concentration was easily noted by the tasters (100\%) interfering negatively in the characteristic coffee aroma. Consequently, the concentration of the volatiles in the beverage was reduced to 50, 30 , and 20 p.p.b. For the preliminary tests, a concentration of 20 p.p.b. was chosen because $50 \%$ of the tasters noticed the addition of this mixture at this level, but no discrimination occurred. This preliminary study was aimed at preparing a sample in which the addition of the volatiles was not noticed as undesirable.

\subsection{Confirmation of a compounds mixture threshold of 20 p.p.b. in the coffee beverage}

To confirm the results obtained in the preliminary examination of the mixture of compounds in the black instant coffee beverage, the triangle test was applied again. In this case, a larger number of consumers were used. The sensory team was now composed by sixty coffee consumers including eight smokers. The triangle test was used because it is simple to apply and provides explicit results clearly showing whether there are significant differences between the samples or not. For the tests, the tasters received three randomly coded samples and were informed that two of them were the same and one was different. The tasters tested the samples from left to right and identified the different sample (MEILGAARD; CIVILLE; CARR, 1987).

Sample (A) was the black beverage prepared with freezedried instant coffee and sample (B) was the same beverage to which the volatile solution (20 p.p.b. $-0.3 \mathrm{~mL}$ of a $0.1 \%$ solution per $150 \mathrm{~mL}$ of instant coffee beverage) was added. The samples were randomly coded with three- digit numbers and presented according to a complete block design in which the positions were repeated for given number of times avoiding the negative effects related to sample presentation. The tasters received the samples together, all at the same temperature $\left(70^{\circ} \mathrm{C}\right)$, in trays provided with a cookie, a glass of water, and a sensory analysis sheet with the following message: "You are receiving three soluble coffee samples; two are the same and one is different. Please indicate the number corresponding to the different sample". Also, in the score sheet used in the triangle test, the tasters were requested to provide commentaries when needed.

The analyses were carried out in the Sensory Analysis Laboratory of the Food and Nutrition Department of the State University of Campinas (DEPAN - UNICAMP) in individual booths avoiding communication that could interfere with the results.

\subsection{Acceptance test}

The acceptance test was used to verify whether the consumer liked or disliked the product associated with the coffee aroma and flavor attributes. The test was performed in five sessions, in which one sample was tested once (mono presentation) in two daily sessions (STONE; SIDEL, 1993). The sample (Table 1) was randomly presented and the order presentation was counter-balanced across the tasters. The time of the sessions was from 9-11:00 am and from 2-5:30 pm, and they were carried out according to the time that the tasters usually drink coffee. Samples to which the mixture of compounds had been added (20 p.p.b.) were presented individually to the tasters in trays containing one sensory analysis sheet, sugar or sweetener, and a glass of water.

Fifty consumers evaluated the coffee aroma and flavor attributes of the five samples in different sessions using a hedonic scale. They were also asked to state what they most liked and/or disliked in each sample. The acceptance tests were performed under the same conditions as the triangle tests considering the location and booths.

The results were evaluated by the analysis of variance (ANOVA) considering as main effects samples and tasters (two sources of variation) and the Tukey's test ( $\mathrm{p} \leq 0.5)$ (STEEL; TORRIE, 1980) using the SAS program (Statistical Analysis System - Cary, NC, USA).

\section{Results and discussion}

\subsection{Examination for the detection threshold of the volatile compounds mixture in black instant coffee beverages}

The triangle test was applied to examine the threshold of the mixture added to the black instant coffee beverage both in 
the preliminary and confirmation tests. The confirmation test was performed to verify if the level of 20 p.p.b. represented a concentration at which no discrimination occurred when the number of tasters was from eight to sixty. Fifty eight percent of the tasters could differentiate the samples of black instant coffee beverage with and without the mixture of five compounds at a level of significance of $p \leq 0.01$. Considering that $50 \%$ of the tasters could identify the difference when there were only eight tasters and $58 \%$ when the team was composed by sixty tasters, the concentration of 20 p.p.b. in the five compounds in the beverage was chosen to be used in the acceptance tests.

In the comments provided during the triangle tests, many tasters characterized the coffee flavor of the beverage as weak and others commented that it was difficult to notice the difference.

\subsection{Acceptance test}

Fifty consumers took the acceptance test to verify if the black instant coffee beverage, to which the mixture of volatile compounds had been added, would make the beverage more acceptable considering the coffee aroma and flavor attributes.

From the analysis of variance performed with the results from each taster (source of variation: sample and taster) $\left(\mathrm{p}_{\mathrm{F}}\right.$ value) for the coffee aroma (Table 2 ) and flavor (Table 3 ), it was possible to observe that there was a significant difference at a level of $p \leq 0.05$ between the least two samples. It could also be observed that there was a significant difference between the tasters, but this difference is normally due to the degree of liking or disliking, which varies from taster to taster, who may express the same feeling at different positions on the hedonic scaling. Table 4 shows the average for the coffee aroma and flavour attributes obtained for each of the samples related to the taster's evaluation using the hedonic scale.

Samples of freeze-dried instant coffee $(3,4$, and 5$)$ did not differ significantly from each other when the coffee aroma and flavor attributes were considered. Samples prepared with spraydried instant coffee, samples 1 and 2, did not differ from each other either. However, for the coffee aroma attribute, samples 1 and 2 (spray-dried instant coffee) were less accepted showing a significant difference from samples 4 and 5 but no difference from sample 3 (freeze-dried instant coffee to which the mixture of compounds was added). Samples 4 and 5 received values between 6 and 7 on the hedonic scale, which are equivalent to: "I slightly liked it" and "I moderately liked it", respectively, showing that these beverages prepared with freeze-dried instant coffee were well accepted when compared with samples 1 and 2 , spray-dried instant coffee samples (Table 4).

For the coffee flavor attribute (Table 4), the freeze-dried instant coffee beverage, to which the roasted coffee aromatic oil (sample 5) and the mixture of compounds (sample 3 ) had been added, presented significant differences from the spraydried instant coffee beverage with and without the addition of the mixture of compounds (samples 1 and 2). Nevertheless, significant differences did not occur among the samples of freeze-dried instant coffee without the mixture of compounds (sample 4) and the spray-dried instant coffee ones (1 and 2). Spray-dried instant coffee samples (1 and 2) presented lower values than the freeze-dried ones ( 3 and 5) showing that the enrichment of the beverage prepared with freeze-dried coffee containing the mixture of the five volatiles or the roasted coffee oil could be differentiated from the samples prepared with instant coffee for this attribute.

\section{Conclusion}

Some samples showed significant differences for the aroma and flavor coffee attributes. Black freeze-dried instant coffee beverages showed better sensory characteristics or acceptance $(p \leq 0.05)$ than the spray-dried ones. However, considering the aroma attribute for sample 3 and the flavor attribute for sample 4 , this difference could not be observed whatsoever.

The sample of black freeze-dried instant coffee to which the aromatic roasted coffee oil was added showed higher acceptance than the other samples, but there was no significant difference for the same sample to which the mixture of the five compounds was added. This indicates that the impact caused in the coffee aroma and flavor of the beverage when the five aromatic compounds were added or the roasted coffee aromatic oil was added could be the same.

The coffee aroma and flavor of the freeze-dried instant coffee samples to which the five aromatic compounds were added did not present a significant difference when compared to the samples without the mixture showing that the impact of these aromatic compounds in the beverage was not relevant with respect to these attributes. Considering only coffee aroma, the sample with the highest acceptance was the freeze-dried instant coffee without the five aromatic compounds (4). Nevertheless,

Table 2. Analyses of variance of the coffee aroma attribute.

\begin{tabular}{lcrccc}
\hline $\begin{array}{l}\text { Source of } \\
\text { variation }\end{array}$ & $\begin{array}{c}\text { Degrees of } \\
\text { freedom }\end{array}$ & $\begin{array}{r}\text { Sum of } \\
\text { squares }\end{array}$ & $\begin{array}{c}\text { Mean } \\
\text { square }\end{array}$ & $F$ test & $\mathrm{p}_{\mathrm{F}}$ \\
\hline Sample & 4 & 40.856 & 10.214 & 5.79 & 0.0002 \\
Taster & 49 & 400.896 & 8.182 & 4.64 & 0.0010 \\
Residue & 196 & 345.944 & 1.765 & & \\
Total & 249 & 787.696 & & & \\
\hline
\end{tabular}

Table 3. Analyses of variance for the coffee flavor attribute.

\begin{tabular}{lcrccc}
\hline $\begin{array}{l}\text { Source of } \\
\text { variation }\end{array}$ & $\begin{array}{c}\text { Degrees of } \\
\text { freedom }\end{array}$ & $\begin{array}{c}\text { Sum of } \\
\text { square }\end{array}$ & $\begin{array}{c}\text { Mean } \\
\text { square }\end{array}$ & $F$ test & $\mathrm{p}_{\mathrm{F}}$ \\
\hline Sample & 4 & 41.976 & 10.494 & 5.41 & 0.0004 \\
Taster & 49 & 487.956 & 9.958 & 5.17 & 0.0001 \\
Residue & 196 & 377.624 & 1.927 & & \\
Total & 249 & 907.556 & & & \\
\hline
\end{tabular}

Table 4. Average values obtained in the acceptance test using a hedonic scale for five samples of instant coffee.

\begin{tabular}{cccc}
\hline \multicolumn{2}{c}{ Coffee aroma $\left(\right.$ Tukey $\left.^{*}\right)$} & \multicolumn{2}{c}{ Coffee flavour $\left(\right.$ Tukey $\left.^{*}\right)$} \\
\hline Sample & Mean & Sample & Mean \\
\hline 4 & $6.6^{\mathrm{a}}$ & 5 & $6.4^{\mathrm{a}}$ \\
5 & $6.4^{\mathrm{a}}$ & 3 & $6.3^{\mathrm{a}}$ \\
3 & $6.2^{\mathrm{ab}}$ & 4 & $6.2^{\mathrm{ab}}$ \\
1 & $5.9^{\mathrm{b}}$ & 2 & $5.4^{\mathrm{b}}$ \\
2 & $5.4^{\mathrm{b}}$ & 1 & $5.4^{\mathrm{b}}$ \\
\hline
\end{tabular}

${ }^{*}$ Means with the same letter within column are not significantly different $(\mathrm{p} \geq 0.05)$. 
this result did not show significant differences when compared to the other freeze-dried coffee beverage samples. Considering these results and the value obtained on the hedonic scale, it was possible to observe that instant coffee obtained by the freezedrying process, samples 4 and 5 for the aroma attribute and samples 3 and 5 for the flavor attribute, showed higher quality presenting significant difference only in the beverage prepared with spray-dried instant coffee. Especially for the flavor attribute, it was possible to conclude that the mixture of volatiles or the roasted coffee oil added in the coffee beverage prepared with freeze-drying instant coffee could enhance the tasters' acceptance when compared with the beverage using spray-dried instant coffee without the mixture of compounds (1) or when the mixture of volatiles was added (2).

\section{Acknowledgements}

The authors are grateful for the financial support provided by FAPESP (The State of São Paulo Research Foundation process $96 / 11904-0)$.

\section{References}

SARRAZIN, C. et al. Representativeness of coffee aroma extracts: a comparision of different extraction methods. Food Chemistry, v. 70, n. 1, p. 99-106, 2000.

RAMOS, E. et al. Obtention of brewed coffee aroma extract by optimized supercritical $\mathrm{CO}_{2}$-based process. Journal of Agricultural and Food Chemistry, v. 46, n. 10, p. 4011-4016, 1998.

OLIVEIRA, A. L. et al. Sensory and yield response surface analysis of supercritical $\mathrm{CO}_{2}$ extracted aromatic oil from roasted coffee. Journal of Food Science and Technology, v. 38, n. 1, p. 38-42, 2001.

NIJSSEN, L. R. et al. Volatile compounds in food. The Netherlands, TNO-CIVO, 1996.

HOLSCHER, W.; VITZTHUM, O. G.; STEINHART, H. Phenyl alcohol - Source for Odorants in roasted coffee. Journal of Agricultural and Food Chemistry, v. 40, n. 4, p. 655-658, 1992.

SEMMELROCH, P.; GROSCH, W. Analysis of roasted coffee powders and brews by gas chromatography-olfactometry of headspace samples. Lebensmittel-Wissenschaft und-Technologie, v. 28, n. 4, p. 310-313, 1995.

POLLIEN, P.; KREBSD, Y.; CHAINTREAU, A. Comparison of a brew and an instant coffee using a new GC-Olfactrometric method. In: INTERNATIONAL SCIENTIFIC COLOQUIUM ON COFFEE, 17, 1997. Proceedings... Nairobi: Association Scientifique Internationale du Café, 1997.

MAYER, F.; CZERNY, M.; GROSCH, W. Sensory study of the character impact aroma compounds of coffee beverage. European Food Research and Technology, v. 211, n. 4, p. 272-276, 2000.
SEMMELROCH, P.; GROSCH, W. Studies on character impact odorants of coffee brews. Journal of Agricultural and Food Chemistry, v. 44, n. 2, p. 537-543, 1996.

MAEZTU, L. et al. Characterization of espresso coffee aroma by static headspace GC-MS and Sensory flavour profile. Journal of Agricultural and Food Chemistry, v. 49, n. 11, p. 5437-5444, 2001.

ELMORE, J. S.; NURSTEN, H. E. The effect of 2-furanmethanethiol upon the flavour of instant coffee. International Journal of Food Science and Technology, v. 28, n. 5, p. 531-536, 1993.

BLANK, I.; GROSCH, W. On the role of (-)-2-methylisoborneol for the aroma of robusta coffee. Journal of Agricultural and Food Chemistry, v. 50, n. 16, p. 4653-4656, 2002.

BASSOLI, D. G. et al. Instant coffee with natural aroma by spray-drying. In: INTERNATIONAL SCIENTIFIC COLOQUIUM ON COFFEE, 15, 1993. Proceedings... Montpellier: Association Scientifique Internationale du Café, 1993, p. 712-718.

CALVIÑO, A. M.;ZAMORA, M. C.; SARCHI, M. I. Principal components and cluster analysis for descriptive sensory assessment of instant coffee. Journal of Sensory Studies, v. 11, n. 3, p. 191-210, 1996.

ZAMORA, M. C.; CALVINO, A. M. A comparison of methodology applied to the selection of a panel for sensory evaluation of instant coffee. Journal of Sensory Studies, v. 11, n. 3, p. 211-226, 1996.

JONG, S.; HEIDEMA, J.; VAN DER KNAAP, C. M. Generalized procrusters analysis of coffee brands tested by five european sensory panels. Food Quality and Preference, v. 9, n. 3, p. 111-114, 1998.

OLIVEIRA, A. L.; CABRAL, F. A.; EBERLIN, M. N. Prediction of solubility of some compounds of roasted coffee aromatic oil in supercritical CO2. In: INTERNATIONAL SYMPOSIUM ON SUPERCRITICAL FLUIDS, Proceedings... Versailles: International Society for Advancement of Supercritical Fluids, 2003.

WANG, T. H.; SHANFIELD, H.; ZLATKIS, A. Analysis of trace volatile organic compounds in coffee by headspace concentration and gas chromatography-mass spectrometry. Chromatographia, v. 17, n. 8, p. 411-417, 1983.

HASHIM, L.; CHAVERON H. Use of methylpyrazine ratios to monitor the coffee roasting. Food Research International, v. 28, n. 6, p. 619-623, 1996.

ROBERTS, D. D.; POLLIEN, P.; MILO, C. Solid-phase microextraction method development for headspace analysis of volatile flavour compounds. Journal of Agricultural and Food Chemistry, v. 48, n. 6, p. 2430-2437, 2000.

RIVETTI, D. et al. Effect of water composition and water treatment on expresso coffee percolation. In: INTERNATIONAL SCIENTIFIC COLOQUIUM ON COFFEE, Proceedings... Trieste: Association Scientifique Internationale du Café, 2001.

MEILGAARD, M.; CIVILLE, G. V.; CARR, B. T. Sensory evaluation techiniques. Boca Raton: CRC Press, 1987.

STONE, H.; SIDEL, J. L. Sensory evaluation practices. London: Academic Press, 1993.

STEEL, R. G. D.; TORRIE, J. H. Principles and Procedures of Statistics A Biometrical Approach. Singapura: McGraw-Hill, 1980. 